\title{
Understanding the local chemical environment of bioelectrocatalysis
}

\author{
Esther Edwardes Moore ${ }^{a}$, Samuel J. Cobb $^{a}{ }^{\circ}$, Ana Margarida Coito ${ }^{b}{ }^{\circ}$, Ana Rita Oliveira $^{\mathrm{b}}{ }^{\circ}$, Inês A. C. Pereira ${ }^{\mathrm{b}}{ }^{\circ}$, and \\ Erwin Reisner ${ }^{a, 1}$ (D)

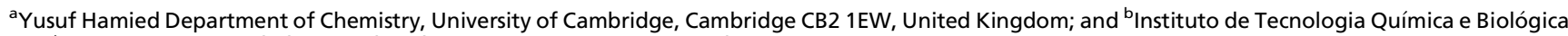 \\ António Xavier, Universidade Nova de Lisboa, 2780-157 Oeiras, Portugal
}

Edited by Nicolas Plumeré, Technische Universität München; received July 30, 2021; accepted November 16, 2021 by Editorial Board Member Marcetta Y. Darensbourg

\begin{abstract}
Bioelectrochemistry employs an array of high-surface-area mesoand macroporous electrode architectures to increase protein loading and the electrochemical current response. While the local chemical environment has been studied in small-molecule and heterogenous electrocatalysis, conditions in enzyme electrochemistry are still commonly established based on bulk solution assays, without appropriate consideration of the nonequilibrium conditions of the confined electrode space. Here, we apply electrochemical and computational techniques to explore the local environment of fuel-producing oxidoreductases within porous electrode architectures. This improved understanding of the local environment enabled simple manipulation of the electrolyte solution by adjusting the bulk $\mathrm{pH}$ and buffer $\mathrm{pK}_{\mathrm{a}}$ to achieve an optimum local $\mathrm{pH}$ for maximal activity of the immobilized enzyme. When applied to macroporous inverse opal electrodes, the benefits of higher loading and increased mass transport were employed, and, consequently, the electrolyte adjusted to reach $-8.0 \mathrm{~mA} \cdot \mathrm{cm}^{-2}$ for the $\mathrm{H}_{2}$ evolution reaction and $-3.6 \mathrm{~mA} \cdot \mathrm{cm}^{-2}$ for the $\mathrm{CO}_{2}$ reduction reaction $\left(\mathrm{CO}_{2} \mathrm{RR}\right)$, demonstrating an 18-fold improvement on previously reported enzymatic $\mathrm{CO}_{2} \mathrm{RR}$ systems. This research emphasizes the critical importance of understanding the confined enzymatic chemical environment, thus expanding the known capabilities of enzyme bioelectrocatalysis. These considerations and insights can be directly applied to both bio(photo)electrochemical fuel and chemical synthesis, as well as enzymatic fuel cells, to significantly improve the fundamental understanding of the enzyme-electrode interface as well as device performance.
\end{abstract}

bioelectrochemistry | enzymes | $\mathrm{CO}_{2}$ reduction | hydrogen evolution local pH

E nzymatic electrochemistry has rapidly expanded into research fields that encompass applications across disciplines from fundamental understanding of enzymology to biosensors, biofuel cells, and semiartificial photosynthesis $(1,2)$. Hydrogenases ( $\mathrm{H}_{2}$ ases) combine protons and electrons to reversibly produce $\mathrm{H}_{2}$ at the thermodynamic potential using $\mathrm{Fe}$ or $\mathrm{NiFe}$ active sites and have therefore been extensively studied as a model system for reversible electrocatalysis $(3,4)$. Formate dehydrogenases (FDHs) have similarly garnered attention due to their ability to reversibly reduce $\mathrm{CO}_{2}$ to formate, with high selectivity when immobilized on an electrode (5-8). Bioelectrochemistry on thin-film electrodes has long provided mechanistic and analytical insight into enzyme function as well as established bioelectrolysis as a potential method of product synthesis $(1,3,9)$. Porous electrodes enable higher enzyme loading, and hence higher current densities, improving the overall performance by increasing the consumption or production of desired chemicals (10-15).

Solution assays provide insight into the influence of bulk $\mathrm{pH}$ and ionic strength on enzyme activity, and the conclusions have informed the choice of electrolyte in electrochemical studies $(16,17)$. However, the high current densities achievable using the latest generation of high-surface-area electrode scaffolds, usually used as stationary electrodes, present a significantly different local chemical environment during turnover to that of bulk solution assays. With enzymes operating at a high rate of catalysis, for example Desulfovibrio vulgaris Hildenborough $(D v \mathrm{H})[\mathrm{NiFeSe}]-\mathrm{H}_{2}$ ase has a turnover frequency (TOF) of $\sim 8,300 \mathrm{~s}^{-1}$ for $\mathrm{H}_{2}$ evolution (18), the local proton concentration is likely to change significantly if the enzyme is placed in a porous environment. Therefore, consideration of local concentration gradients, as opposed to the bulk electrolyte solution, appears to be critical to understand and optimize enzymatic activity in such porous electrodes.

The precise conditions of the local chemical environment are decisive for enzyme activity, and the local environment must therefore be tailored to the nature of the immobilized enzyme for optimal catalysis. Both the enzymatic $\mathrm{H}_{2}$ evolution reaction (HER) (Eq. 1) and formate production by the enzymatic $\mathrm{CO}_{2}$ reduction reaction $\left(\mathrm{CO}_{2} \mathrm{RR}\right)$ (Eq. 2) involve the net consumption of protons as part of their mechanism, leading to an increased local $\mathrm{pH}$ at the electrode surface $(19,20)$. Due to their high activity and selectivity, $\mathrm{H}_{2}$ ases can provide a simple, illustrative model system of how catalysis causes local $\mathrm{pH}$ changes within porous architectures, while FDHs can demonstrate the effect for the $\mathrm{CO}_{2} \mathrm{RR}$.

\section{Significance}

Enzyme bioelectrochemistry concerns the integration of oxidoreductase enzymes into electrodes to enable and study the transfer of electrons between the solid-state material surface and the biological catalyst. To achieve higher enzyme loading, and hence greater current densities, highsurface-area strategies have been employed to immobilize enzymes, but these porous electrode architectures amplify the formation of local chemical gradients. Enzyme selectivity and activity is highly dependent on such changes in local environment, such as substrate concentration, $\mathrm{pH}$, and electrolyte species concentration. Here, electrochemistry and computational techniques are applied to explore, and hence optimize, the local environment of the fuel-producing oxidoreductases, hydrogenase and formate dehydrogenase, within porous electrodes.

Author contributions: E.E.M. and E.R. designed research; E.E.M. performed experimental research; S.J.C. performed computational modelling; A.M.C., A.R.O., and I.A.C.P. provided the enzymes and performed solution studies; E.E.M., S.J.C., and E.R. analyzed data; and E.E.M. and E.R. wrote the paper.

The authors declare no competing interest.

This article is a PNAS Direct Submission. N.P. is a guest editor invited by the Editorial Board.

This article is distributed under Creative Commons Attribution-NonCommercialNoDerivatives License 4.0 (CC BY-NC-ND).

${ }^{1}$ To whom correspondence may be addressed. Email: reisner@ch.cam.ac.uk.

This article contains supporting information online at http://www.pnas.org/lookup/ suppl/doi:10.1073/pnas.2114097119/-/DCSupplemental.

Published January 20, 2022 


$$
\begin{gathered}
2 \mathrm{H}^{+}{ }_{(a q)}+2 e^{-} \rightleftharpoons \mathrm{H}_{2(g)} \\
\mathrm{CO}_{2(a q)}+2 e^{-}+\mathrm{H}^{+}{ }_{(a q)} \rightleftharpoons \mathrm{HCOO}^{-}{ }_{(a q)}
\end{gathered}
$$

The local $\mathrm{CO}_{2} \mathrm{RR}$ environment has been extensively modeled, and the conclusions have been applied to improve the selectivity of heterogeneous (21-25) and heterogenized molecular catalysts (26-29). Due to competition between HER and $\mathrm{CO}_{2} \mathrm{RR}$ when using synthetic catalysts, compromises, such as basicity, are often made to minimize the HER even at the cost of $\mathrm{CO}_{2} \mathrm{RR}$ activity due to the overall benefit of selectivity $(30,31)$. The complexity of these interfacial interactions is considerably reduced when considering enzymatic catalysis due to the inherent specificity, selectivity, and low overpotential requirements of the protein to drive catalysis $(32,33)$. Without the competing HER, the local environment in enzymatic systems can be controlled without compromise to facilitate the $\mathrm{CO}_{2} \mathrm{RR}$. Therefore, enzymatic $\mathrm{CO}_{2}$ electroreduction provides a paragon for the development of more "ideal" synthetic molecular catalysts in the future.

Here, the local chemical environment of enzymatic HER and $\mathrm{CO}_{2} \mathrm{RR}$ systems was studied by bioelectrochemistry and computational methods using a finite element model (FEM). First, for the HER and then for the $\mathrm{CO}_{2} \mathrm{RR}$, the change in local $\mathrm{pH}$ on mesoporous electrodes was studied bioelectrochemically by the current density obtained in solutions with buffers of different $\mathrm{pK}_{\mathrm{a}}$. For this purpose, $D v \mathrm{H}[\mathrm{NiFeSe}] \mathrm{H}_{2}$ ase and $D v \mathrm{H} \mathrm{W}-\mathrm{FDH}$ were chosen as enzymes with high activity for their respective reduction reactions and low product inhibition (SI Appendix, Fig. S1) $(16,34)$. The $\mathrm{pH}$-activity solution assays for $\mathrm{H}_{2}$ ase and FDH had previously been undertaken, showing an optimum $\mathrm{pH}$ of 6 and 7.1, respectively (SI Appendix, Fig. S2). Independently, a FEM was developed from basic physical principles and enzyme-activity dependence studies for $\mathrm{pH}$, buffer concentration, and substrate concentration. The accuracy of the model was then confirmed by predicting the current density outcome of each experiment. The excellent match between the experimental and simulated results validated the FEM; hence, the model could be used to simulate the changes in local $\mathrm{pH}$ and other species concentrations. The model was then used to iterate the optimum conditions for each system, and the resulting increase in current density was demonstrated experimentally. Finally, the conclusions were experimentally tested on a different electrode architecture, an inverse opal electrode, to demonstrate the wide-ranging applicability of this study.

\section{Results and Discussion}

Methodology and Simulation. To demonstrate the effect of local chemical environment changes in confined electrodes, first, a mesoporous indium-tin-oxide (mesoITO) film on fluorinedoped tin oxide (FTO)-coated glass (synthesized $50 \mathrm{~nm}$ ITO particles, film thickness of $8.5 \mu \mathrm{m}$, SI Appendix, Figs. S3-S5) was chosen as the electrode. The mesoporous structure could be simulated as a randomly close packed structure and hence did not require too computationally-expensive modeling. ITO was chosen as the electrode material due to its conductivity and high affinity for enzyme binding and its versatility to prepare porous materials $(10,11,35-41)$. The enzymes, $\mathrm{H}_{2}$ ase for the HER, and $\mathrm{FDH}$ for the $\mathrm{CO}_{2} \mathrm{RR}$ were then immobilized onto the electrode by drop casting. A three-electrode setup was used in the chosen electrolyte solution to measure the resultant current density, and the solution was stirred to maximize mass transport to the electrode. To demonstrate the reproducibility of the findings, at least three repeats were measured for each experiment, each with a newly assembled bioelectrode in a fresh electrolyte solution.

For the electrolyte, two zwitterionic Good's buffers were selected for this study: 2-(N-morpholino)ethanesulfonic acid (MES) $\left(\mathrm{pK}_{\mathrm{a}}=6.27\right)$ and 3 - $(N$-morpholino $)$-propanesulfonic
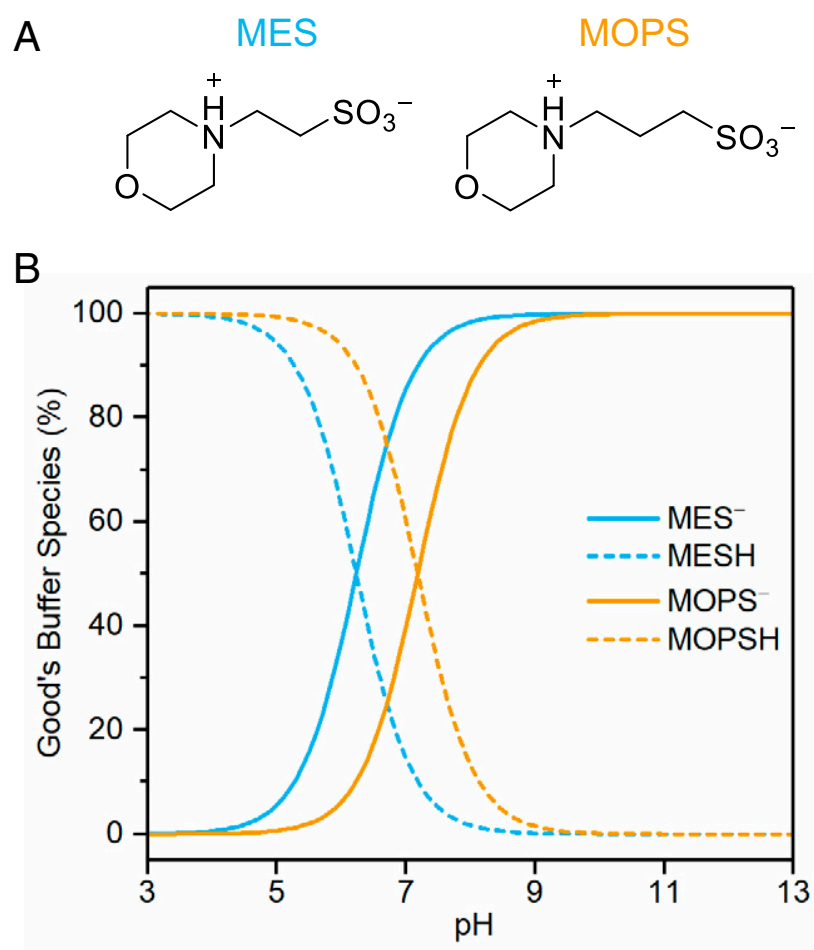

Fig. 1. Analysis of Good's buffer species MES and MOPS. ( $A$ ) Chemical structure of MES and MOPS zwitterions. $(B)$ Graph demonstrating the theoretical change in ratio of each buffer species MES (blue) and MOPS (orange) with $\mathrm{pH}$ (protonated Good's buffer shown as a dashed line and anion as a solid line).

acid (MOPS) $\left(\mathrm{pK}_{\mathrm{a}}=7.18\right)$ (Fig. $1 A$ and $\left.B\right)(42,43)$. These buffers were chosen due to their similar chemical composition to ensure that any changes in enzyme productivity could be attributed to the different $\mathrm{pK}_{\mathrm{a}}$ as opposed to physical or chemical interactions with the electrode or enzyme. These buffers are also known to not coordinate with the main metals present in enzymes and reference electrodes (44). The effect of the specific buffer concentration on the enzyme activity was measured for this study, the results are presented in SI Appendix, Enzyme Current Density, and the buffer concentration has been kept below inhibitory levels throughout this study. The electrolyte solution for the $\mathrm{CO}_{2} \mathrm{RR}$ also contains $\mathrm{CO}_{2}$ and its $\mathrm{pH}$-dependent equilibrium with carbonic acid $\left(\mathrm{H}_{2} \mathrm{CO}_{3}\right)$, bicarbonate $\left(\mathrm{HCO}_{3}^{-}\right)$, and carbonate $\left(\mathrm{CO}_{3}^{2-}\right)$, which has been further discussed in $\mathrm{SI}$ Appendix, Equilibria. To accurately prepare the electrolyte solutions, taking into account the influence of ionic strength, equations to calculate the activity coefficients of all species were applied using the freeware chemical equilibrium model Visual MINTEQ (SI Appendix, Ionic Strength) (45). In initially compared electrolytes, the ionic strength has been kept constant by the addition of $\mathrm{KCl}$. The buffers were prepared by combination of the correct concentration of acid and base buffer species to give the desired bulk $\mathrm{pH}$. The $\mathrm{pH}$ at which MES and MOPS have identical buffer capacity is 6.54 , so this was selected as the bulk pH (Fig. $1 B$ and SI Appendix, Buffer Capacity).

The FEM was constructed to simulate the effect of local environment changes on enzymatic HER $(D v \mathrm{H}$ [NiFeSe] $\mathrm{H}_{2}$ ase) and $\mathrm{CO}_{2} \mathrm{RR}(\mathrm{D} v \mathrm{H}$ W-FDH) in the mesoporous electrode using COMSOL Multiphysics 5.5. Similar models have been applied to follow the concentration of $\mathrm{H}_{2}$ as substrate for $\mathrm{H}_{2}$ oxidation and $\mathrm{O}_{2}$ inhibition in redox hydrogel films or carbon nanotubes, though these models did not consider the concomitant change in local $\mathrm{pH}$ or other electrolyte species 


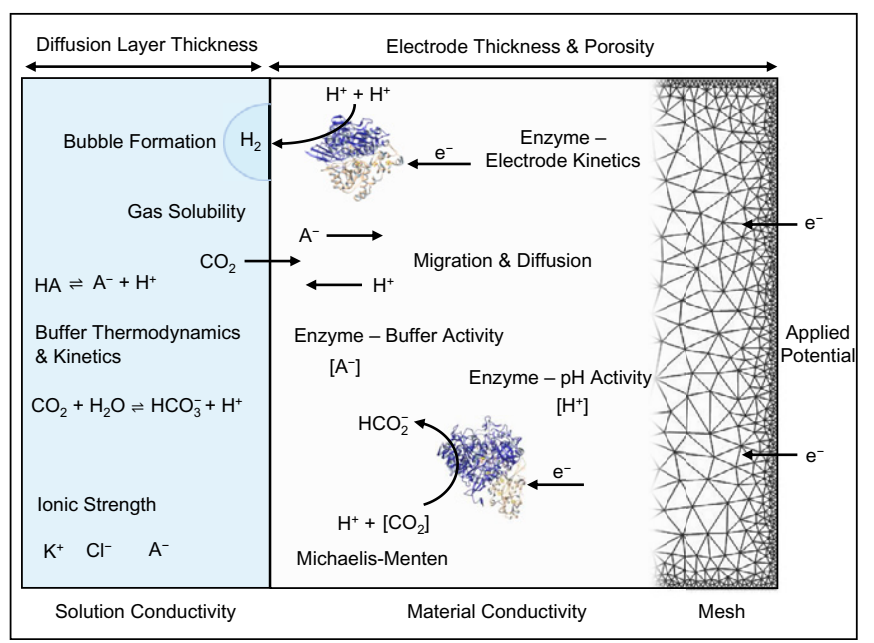

Fig. 2. Graphic illustrating the different parameters, which were considered in the FEM, including enzyme activity dependence, enzyme-electrode kinetics, geometry parameters, solution properties, and potential distributions.

$(46,47)$. The model and its governing parameters and equations are described in detail in SI Appendix, Finite Element Model and are summarized in Fig. 2. A full output report from the COMSOL model has also been included as additional information in Dataset.

The model uses the Nernst-Planck equation to describe the potential distribution within the electrode, alongside the kinetics of the enzyme, which is assumed to be homogenously distributed within the porous electrode. Furthermore, known modifiers of enzyme activity, such as $\mathrm{pH}$ and substrate concentration that are described using common analytical expressions such as Michaelis-Menten kinetics, are included where appropriate. Finally, this is combined with a mass transport model that incorporates the kinetics and thermodynamics of solution reactions. This approach gives a model that is predictive of electrode currents and performance and, critically, is completely independent of the experimental data. This prediction of experimental currents across a range of conditions and the excellent agreement of the predicted and experimental values provides validation of the model. Furthermore, it is indicative of the absence of additional unconsidered interactions, demonstrating that a more comprehensive analysis than that presented was not required.

Once the model was validated, it was used to simulate a quantified understanding of the previously inaccessible local environment, demonstrating the time-dependent changes in the local $\mathrm{pH}$ and other species concentrations. The predictive nature of this FEM could then allow the solution composition to be iterated for the best experimental system performance and highest simulated current densities, which were then validated experimentally. Once the local environment had been optimized for the enzymatic HER and $\mathrm{CO}_{2} \mathrm{RR}$ on mesoporous electrodes, a novel electrode architecture was introduced to demonstrate the applicability of the conclusions on electrolyte composition to a different system. Hierarchical inverse opal (IO) electrodes were chosen due to their macro- and mesoporous structure, which enables increased enzyme loading compared to purely mesoporous electrodes, as has been previously demonstrated $(10,48)$. A shift to $\mathrm{TiO}_{2}$ also allowed the application of more negative reduction potentials $(-0.8 \mathrm{~V}$ versus standard hydrogen electrode [SHE]) than that being used with mesoITO $(-0.6 \mathrm{~V}$ versus SHE) due to the degradation of ITO at more reducing potentials. The IO$\mathrm{TiO}_{2}$ electrodes were constructed with coassembled $\sim 21 \mathrm{~nm}$ anatase $\mathrm{TiO}_{2}$ particles and $750 \mathrm{~nm}$ diameter polystyrene spheres and then annealed to give IO macropores with a total film thickness of $40 \mu \mathrm{m}$ (SI Appendix, Fig. S6). With these electrodes, the principles of local chemical environment adjustment for enzymatic electrochemistry were applied, and hence significant improvements in the current density were again achieved.

Local Chemical Environment of the HER. Electrochemical experiments with $D v \mathrm{H}$ [NiFeSe] $\mathrm{H}_{2}$ ase $(25 \mathrm{pmol})$ on the mesoITO electrode were undertaken in MES and MOPS buffered electrolyte solution. The $100 \mathrm{mM}$ MES electrolyte has been labeled MES, and the $100 \mathrm{mM}$ MOPS electrolyte as MOPS, both with the same buffer capacity at a bulk pH 6.54 (Fig. $1 B$ ). The mesoITO $\mid \mathrm{H}_{2}$ ase electrode in the MOPS electrolyte solution displayed $60 \%$ higher catalytic activity for proton reduction than the MES solution at an applied bias of $-0.6 \mathrm{~V}$ versus SHE (Fig. $3 A$ ). The $\mathrm{H}_{2}$ produced was measured by gas chromatography of a sample of the reaction headspace, and a Faradaic efficiency (FE) of (88 $\pm 5) \%$ was determined (Fig. $3 B$ ). The average current density of the repeats, with a new bioelectrode in new electrolyte for each repeat, has been shown as the solid line with the standard deviation (SD) $(n \geq 3)$ as the shaded area/error bars. The reproducibility of the system is demonstrated by the narrow SD of both the current density and the product quantification. Voltammetry of the mesoITO $\mid \mathrm{H}_{2}$ ase and mesoITO electrodes are also shown in SI Appendix, Fig. S7, showing minimal current density for the enzyme-free control electrodes.

As described in Methodology and Simulation, the experimental system was also simulated using a FEM and the predicted current density is shown as a dotted line over the experimental results (Fig. $3 A$ ). Assuming a FE of $100 \%$, the predicted $\mathrm{H}_{2}$ evolution is shown as separate bars in Fig. $3 B$. The simulated current densities were in close agreement with the experimental data for both the MES and MOPS electrolytes, supporting the validity of the model and its description of the enzyme kinetics, activity, and solution mass transport. With the FEM matching the experimental conditions and outcomes, the model was then used to simulate the changes in local $\mathrm{pH}$ and buffer capacity within the electrode over time (Fig. $3 C$ and $D$ ) and as a function of distance from the electrode (SI Appendix, Fig. S8). Consideration of the local $\mathrm{pH}$ changes within both the porous electrode and the diffusion layer was required to produce an accurate simulation.

Due to the change in local proton concentration as the catalysis occurs, the $\mathrm{pH}$ at the electrode instantly increases (Fig. $3 C$ ). The peak activity of proton reduction by $D v \mathrm{H}$ [NiFeSe] $\mathrm{H}_{2}$ ase in solution assays was shown to be at $\mathrm{pH} 6$, with a reasonably sharp decrease in activity on deviation from the optimum (SI Appendix, Fig. S2) (34). Therefore, as the local pH increases away from the optimum, a decrease in the rate of catalysis of the enzyme will occur. However, the change in local proton concentration is reduced when using an electrolyte solution with a high buffer capacity at that local $\mathrm{pH}$ (Fig. 3D). Therefore, we observe a lower local $\mathrm{pH}$ change in the electrodes for the MOPS buffer $\left(\mathrm{pK}_{\mathrm{a}}=7.2\right)$ compared with MES $\left(\mathrm{pK}_{\mathrm{a}}=6.3\right)$ at a local $\mathrm{pH}$ of $>7.5(\Delta \mathrm{pH}=1.24$ and 1.76 for MOPS and MES, respectively). Consequently, the enzyme activity is higher with the MOPS electrolyte solution, and therefore, higher experimental current densities were observed than when using MES solution (Fig. $3 A$ ). This can additionally be observed in the decrease in current density between the first and second scan of the initial voltammetry scans (SI Appendix, Fig. S9).

With minimal migration and little variation in the electrolyte potential throughout the diffusion layer (SI Appendix, Fig. $\mathrm{S} 10 A$ ), we conclude that the change in local $\mathrm{pH}$ was driven by diffusion. The electrode potential was consistent throughout the electrode, ensuring all enzymes experience a comparable potential (SI Appendix, Fig. S10B), but some change is observed in enzyme activity within the film due to the heterogeneity of $\mathrm{pH}$ within the electrode (SI Appendix, Fig. S8). We also 
A

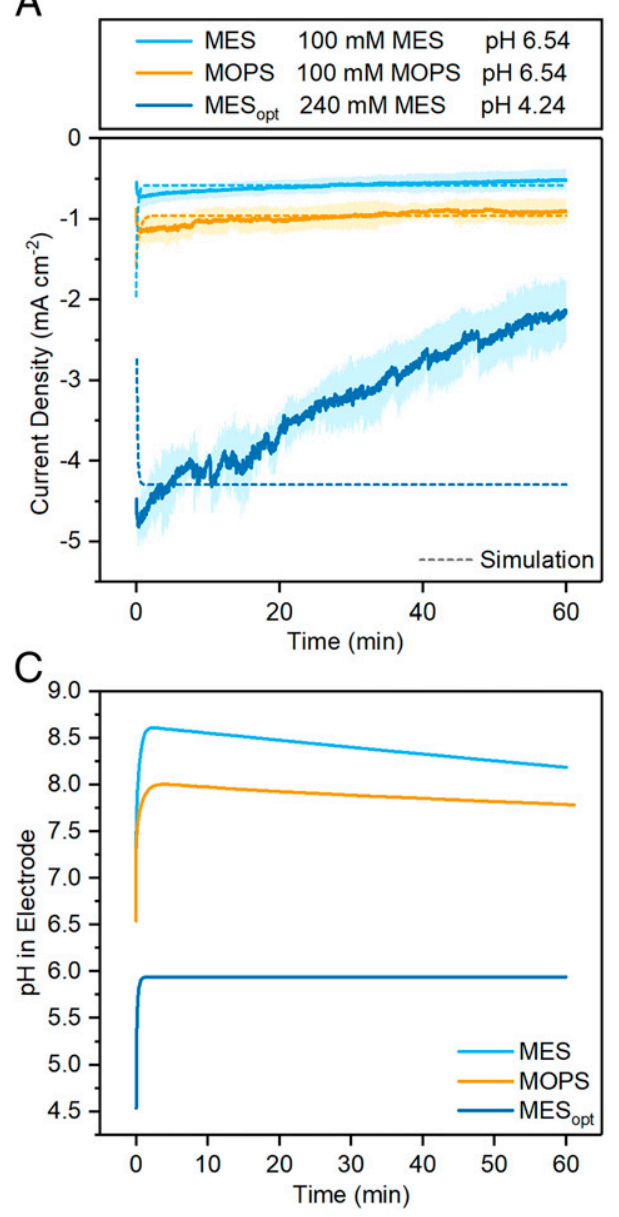

B
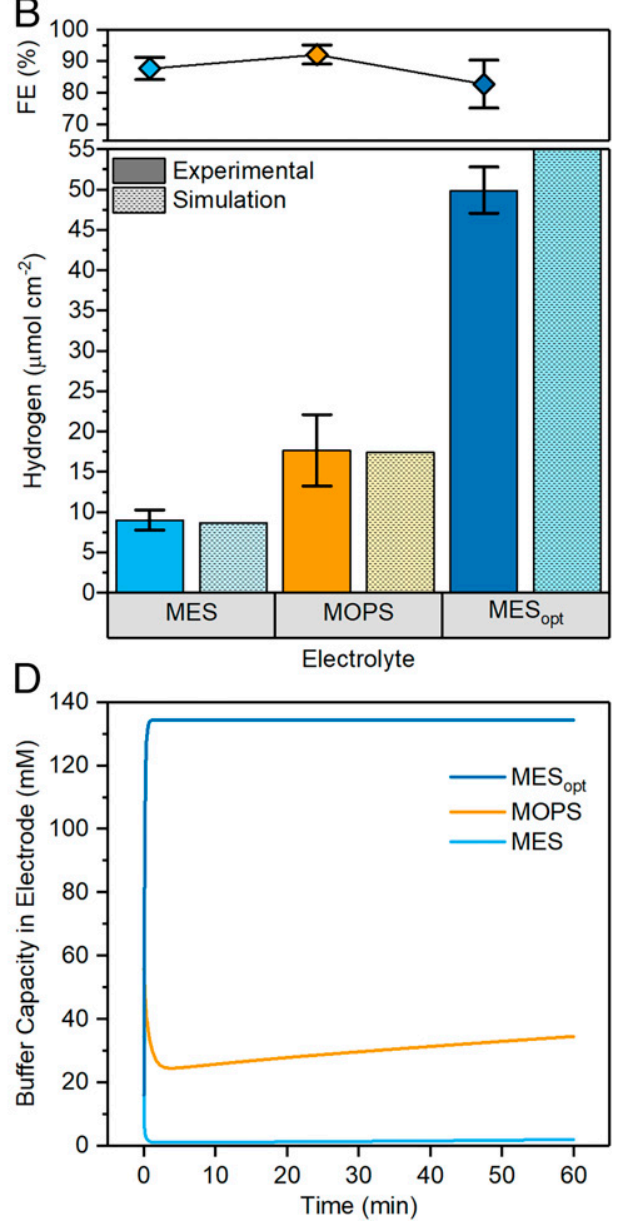

Fig. 3. Bioelectrochemistry of mesolTO $\mid \mathrm{H}_{2}$ ase in MES (blue), MOPS (orange), and the optimum electrolyte MES ${ }_{\text {opt }}$ (dark blue) and simulations demonstrating the local environment changes. $(A)$ Chronoamperometry (CA) of mesolTO $\mathrm{H}_{2}$ ase with an applied bias of $-0.6 \mathrm{~V}$ versus SHE. Experimental data is shown by a solid line with SD as area. Simulated current density is shown by the dashed line. (B) Experimental $\mathrm{H}_{2}$ evolution and $F E_{\mathrm{H}_{2}}$ from $C A$ after 60 min and simulated $\mathrm{H}_{2}$ evolution, assumed $100 \% \mathrm{FE}_{\mathrm{H}_{2}}$, shown by the lighter, dashed bars. (C) Simulated change in the average $\mathrm{pH}$ within the porous electrode during the $60 \mathrm{~min} C \mathrm{CA}$. $(D)$ Simulated change in the average buffer capacity within the porous electrode during the 60 min CA. Conditions: MES (MES [100 mM], KCl [50 mM], pH 6.54 and ionic strength [125 mM]), MOPS (MOPS [100 mM], KCl [105 mM], pH 6.54 and ionic strength [125 mM]). MES (MES [240 mM], $\mathrm{KCl}[175 \mathrm{mM}], \mathrm{pH} 4.24) . \mathrm{H}_{2}$ ase (25 pmol), $\mathrm{N}_{2}$ atmosphere, stirred, $25^{\circ} \mathrm{C}$.

observed minimal potential drop. The combination of experimentation and computation was, therefore, able to demonstrate that porous electrodes with confined enzymes exhibit a significant local $\mathrm{pH}$ change, thereby affecting the current and product output. Consequently, the bulk $\mathrm{pH}$ should not be the optimum $\mathrm{pH}$ for the enzyme but instead should be aligned as to give a local $\mathrm{pH}$ at the optimum. It can also be concluded that the $\mathrm{pK}_{\mathrm{a}}$ of the electrolyte buffer should be matched to the local $\mathrm{pH}$, not the bulk $\mathrm{pH}$. Qualitatively, for $D v \mathrm{H} \mathrm{H}_{2}$ ase HER, the optimum $\mathrm{pH}$ is 6 (SI Appendix, Fig. S2), and therefore, a lower bulk pH of about 4 to 5 would likely be appropriate with a buffer $\mathrm{pK}_{\mathrm{a}}$ of 6 (for example, MES).

Finally, to demonstrate the importance of accounting for the local environment and to show the improvements that result, the FEM was used to predict the optimum solution conditions for $D v \mathrm{H} \mathrm{H}_{2}$ ase $\mathrm{H}_{2}$ evolution on the mesoITO electrode. By iteration of the solution properties in the FEM, the system could be optimized to give the highest predicted current densities, taking into consideration the contrasting effects of MES concentration on enzyme activity (SI Appendix, Enzyme Current Density) and buffer capacity for an optimized local $\mathrm{pH}$. The optimal solution determined by the FEM was an MES concentration of $240 \mathrm{mM}$ and a bulk $\mathrm{pH}$ of 4.24 , which predicted a resulting local $\mathrm{pH}$ of 5.94, closely matching the optimum (pH 6) for HER with $\mathrm{DvH} \mathrm{H} \mathrm{H}_{2}$ ase and a simulated current density of $4.4 \mathrm{~mA} \cdot \mathrm{cm}^{-2}$.

The FEM-suggested optimum conditions $\left(\mathrm{MES}_{\text {opt }}\right)$ were then tested experimentally and gave initial current densities $\left(-4.8 \mathrm{~mA} \cdot \mathrm{cm}^{-2}\right)$ and $\mathrm{H}_{2}$ production $\left(50 \pm 3 \mu \mathrm{mol} \cdot \mathrm{cm}^{-2}\right.$. $\left.\mathrm{h}^{-1}\right) 6$ times the original MES electrolyte solution and close to the predicted value from the FEM (Fig. 3). The reversible nature of the impact of low $\mathrm{pH}$ on enzyme activity was demonstrated by the almost instantaneous return in $\mathrm{MES}_{\text {opt }}$ to high activity despite the low starting $\mathrm{pH}$ of 4.24 . To confirm the computationally derived optimum, a variety of bulk $\mathrm{pH}$ values before and after the optimum were also tested, demonstrating the maximum at pH 4.24 (SI Appendix, Fig. S11). However, the optimized system exhibited deterioration of current densities over the hour. The decrease can be attributed to the build-up of hydrogen gas in the pores and on the electrode as demonstrated by the rejuvenation of the activity after the bubbles were removed from the electrode (SI Appendix, Fig. S12). While the simulation does account for the mass transport effects of bubble formation (SI Appendix, Solution Domain), it does not account for bubble blocking or other effects. For example, $\mathrm{H}_{2}$ bubble formation may cause increased film loss 
through enzyme displacement, reorientation, and degradation. $\mathrm{H}_{2}$ also affects the thermodynamic potential according to the Nernst equation, an effect even more pronounced at the low overpotentials applied here. Though, usually, $\mathrm{H}_{2}$ is a key inhibitor of $\mathrm{H}_{2}$ ases, $D v \mathrm{H}$ [NiFeSe] $\mathrm{H}_{2}$ ase is less susceptible to $\mathrm{H}_{2}$ inhibition as other $\mathrm{H}_{2}$ ases and is hence an ideal candidate for application in confined architectures $(34,49)$. However, if the local concentration was high enough, it is likely that inhibition would still occur. Thus, the simulation does not show the same decline in current density over time and predicts a greater amount of $\mathrm{H}_{2}\left(77.5 \mu \mathrm{mol} \cdot \mathrm{cm}^{-2}\right)$. Therefore, the optimized electrolyte has effectively reached the highest current densities achievable in this electrode system due to the limitations imposed by the production of $\mathrm{H}_{2}$ and other accelerated sources of enzyme-film loss.

Local Chemical Environment of the $\mathbf{C O}_{2} \mathbf{R R}$. $\mathrm{CO}_{2}$, the substrate for $\mathrm{FDH}$, forms the $\mathrm{CO}_{2} / \mathrm{HCO}_{3}^{-}\left(\mathrm{pK}_{1}=6.34\right)$ and $\mathrm{HCO}_{3}^{-} / \mathrm{CO}_{3}^{2-}\left(\mathrm{pK}_{2}\right.$ $=10.32$ ) buffer equilibria when dissolved in $\mathrm{H}_{2} \mathrm{O}$ (SI Appendix, Equilibria). However, on the relatively short timescales within the diffusion layer at the electrode, the slow kinetics of $\mathrm{CO}_{2}$ hydration result in minimal interconversion of $\mathrm{CO}_{2}$ and $\mathrm{HCO}_{3}^{-}$in response to the shifting equilibria. Therefore, the $\mathrm{CO}_{2}$ concentration is almost unchanged by differing $\mathrm{pH}$ within the diffusion layer (50). As such, the buffering effect of $\mathrm{CO}_{2} / \mathrm{HCO}_{3}^{-}$and, similarly, the formation of aqueous $\mathrm{CO}_{2}$ from $\mathrm{HCO}_{3}^{-}$are limited in their mitigation of the local concentration gradients $(28,51,52)$.

In heterogeneous and heterogenized molecular catalyst systems, the poor buffering of the $\mathrm{CO}_{2} / \mathrm{HCO}_{3}^{-}$equilibrium benefits the system by enhancing the local $\mathrm{pH}$ change, which slows down the competing HER, improving selectivity for the $\mathrm{CO}_{2} \mathrm{RR}(22$, 25). However, in enzymatic $\mathrm{CO}_{2} \mathrm{RR}$, the HER is negligible due to high selectivity and low overpotential requirements preventing the HER from occurring directly at the metal oxide electrode. Therefore, increasing the buffer capacity would be beneficial, so an additional, faster-buffering species can be introduced. Three electrolyte solutions were therefore chosen consisting first of a "bicarbonate-only" electrolyte (BC) and then two alternative electrolytes, which include an additional $100 \mathrm{mM}$ buffer as follows: BC-MES and BC-MOPS. A pH of 6.54 was again selected, as at this $\mathrm{pH}$ the buffer capacity of electrolyte BC-MES and BC-MOPS is equal (SI Appendix, Fig. S13A) and the $\mathrm{CO}_{2}$ equilibria species concentrations also do not change between all the electrolytes (SI Appendix, Fig. S13B).

From the electrochemical experiments on a mesoITO scaffold with FDH (52 pmol) at an applied bias of $-0.6 \mathrm{~V}$ versus SHE, we observe significant activity in the BC-MES and further enhanced current in the BC-MOPS electrolyte solution (Fig. $4 A$ ). As before, repeats of each solution were made, and a narrow SD ( $n \geq 3)$ demonstrated the reproducibility of the system.
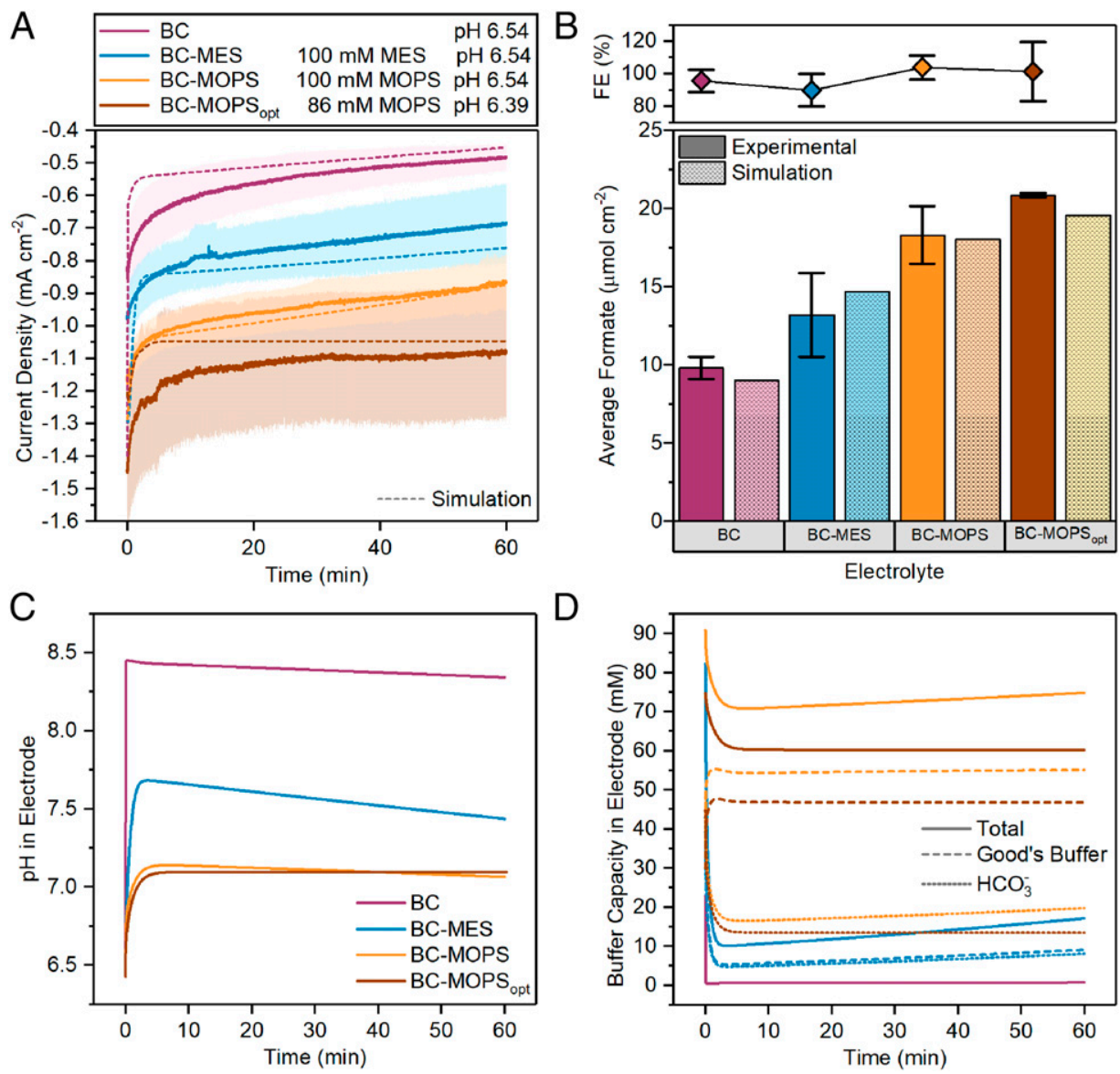

Fig. 4. Bioelectrochemistry of mesolTO|FDH in electrolyte BC (purple), BC-MES (blue), BC-MOPS (orange), and the optimum electrolyte BC-MOPS (brown), and a simulation demonstrating the local environment changes. $(A)$ CA of mesolTO/FDH with an applied bias of -0.6 $\mathrm{V}$ versus SHE. Experimental data is shown by a solid line with error bars as area. Simulated current density is shown by a dashed line. ( $B$ ) Experimental formate production and $F E_{\mathrm{HCOO}^{-}}$from $\mathrm{CA}$ after $60 \mathrm{~min}$ and simulated formate production, assumed $100 \% \mathrm{FE}_{\mathrm{HCOO}^{-}}$, shown by the lighter, dashed bars. (C) Change in the average $\mathrm{pH}$ within the electrode during the $60 \mathrm{~min} C A$. (D) Change in the average total buffer capacity (solid lines) within the electrode during the 60 min CA. The individual buffer capacity of each Good's buffer (dashed lines) and $\mathrm{HCO}_{3}^{-}$(dotted lines) has also been shown. $\mathrm{Conditions:} \mathrm{BC}\left(\mathrm{NaHCO}{ }_{3}[71 \mathrm{mM}\right.$, $\mathrm{KCl}$ [138 mM], pH 6.54), BC-MES (MES [100 mM], $\mathrm{NaHCO}_{3}[72 \mathrm{mM}], \mathrm{KCl}$ [56 mM], pH 6.54), BC-MOPS (MOPS [100 mM], NaHCO ${ }_{3}$ [71 mM], KCl [113 mM], pH

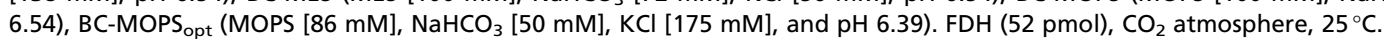


The FEM current density prediction was shown to closely match the experimental results, again confirming the accuracy of the model. The formate production was measured by ion chromatography and displayed an FE of $(97 \pm 7) \%$ (Fig. $4 B)$ and negligible average $\mathrm{H}_{2}$ evolution with a FE of $(0.2 \pm 0.2) \%$, thus demonstrating the excellent selectivity of FDH. The mesoITO electrode without FDH showed minimal current (SI Appendix, Fig. S14).

From the FEM evaluation of the local electrode environment, it is apparent that the local $\mathrm{pH}$ is significantly reduced at the electrode with electrolyte BC-MES and BC-MOPS compared to $\mathrm{BC}$ (Fig. 4C). The highest buffer capacity at the electrode (BC-MOPS) again causes the lowest local pH change (Fig. 4D). A pH of 7.1 has been shown in solution assays to be the optimum $\mathrm{pH}$ of the $\mathrm{FDH}$ for $\mathrm{CO}_{2}$ reduction, and therefore increasing the $\mathrm{pH}$ beyond this optimum decreases enzyme activity (SI Appendix, Fig. S2) (16). While the increased initial buffer capacity of BC-MES improves upon the BC system, the higher $\mathrm{pK}_{\mathrm{a}}$ of MOPS enables a high buffer capacity at the local $\mathrm{pH}$ in BC-MOPS, thus minimizing the local $\mathrm{pH}$ change and increasing activity. Equally, voltammetry of the FDH-modified mesoITO electrode showed a small drop in current density between scan 1 and 2 in electrolyte BC (SI Appendix, Fig. S15), whereas BC-MES and BC-MOPS showed stable current density between successive scans (SI Appendix, Fig. S16), indicative of the smaller change in local $\mathrm{pH}$ in these solutions. The simulation results showing the $\mathrm{pH}$ and buffer capacity as a function of the distance from the surface are shown in SI Appendix, Fig. S17. The local change in $\mathrm{CO}_{2}$ equilibria species concentration over time was also simulated, and the results are discussed in the SI Appendix, Fig. S18.

The experimental data shows continued functionality of the $\mathrm{FDH}$ in electrolyte $\mathrm{BC}$ despite the local $\mathrm{pH}$ increase to 8.4, at which the solution assay suggests $<20 \%$ activity. However, the $\mathrm{CO}_{2}$ concentration would have changed dramatically above $\mathrm{pH}$ 7.5 in the assay, as the addition of $50 \mathrm{mM}$ of $\mathrm{NaHCO}_{3}$ was used to provide $\mathrm{CO}_{2}$ rather than saturated $\mathrm{CO}_{2}$ (16). Therefore, the enzyme may in fact function better at a higher bulk $\mathrm{pH}$ than the assay suggests, as supported by the slightly lower predicted current densities from the FEM model in electrolyte BC. The influence of low $\mathrm{CO}_{2}$ concentration as opposed to the $\mathrm{pH}$ effect on the solution assay is further corroborated by the continued oxidation activity of the enzyme at high $\mathrm{pH}(16)$. These results further demonstrate the importance of considering the effect of $\mathrm{pH}$ on $\mathrm{CO}_{2}$ when designing experiments and suggest that solution assays may be more accurate with saturated $\mathrm{CO}_{2}$.

The FEM was then used to iterate the optimum electrolyte for enzymatic $\mathrm{CO}_{2} \mathrm{RR}$ to provide the greatest predicted currents. The resultant conditions consisted of MOPS $(86 \mathrm{mM})$ and $\mathrm{NaHCO}_{3}(50 \mathrm{mM})$ at a bulk pH of 6.39. Experimentally, this optimum electrolyte $\left({\mathrm{BC}-M O P S_{\text {opt }}}\right)$ gave $20 \%$ higher current densities (Fig. 4), thus showing again that a high buffer capacity and matching the $\mathrm{pK}_{\mathrm{a}}$ of the additional buffer to the local $\mathrm{pH}$, as opposed to the bulk $\mathrm{pH}$, are critical to stabilizing the local $\mathrm{pH}$ and hence maximizing product formation.

Local Chemical Environment of Macroporous Electrodes. The local environment optimization conclusions, derived from the mesoporous electrodes, were then applied to hierarchical IO electrodes to demonstrate their applicability to alternative electrode architectures (SI Appendix, Fig. S6). The mesoporous scaffold enables high loading of the enzyme, while the macropores, formed by a polystyrene sphere coassembly procedure, increase the diffusion of electrolyte species, such as substrates and products, into and out of the electrode. With the $\mathrm{IO}^{-\mathrm{TiO}_{2}}$ electrodes, the loading could be doubled from that used with mesoITO, and more negative reduction potentials $(-0.8 \mathrm{~V}$ versus SHE) were able to be applied. The less-confined IO structure should also increase the mass transport of protons to the local environment of the enzyme, decreasing the local $\mathrm{pH}$ increase caused by catalysis.

First, the IO electrode IO-TiO ${ }_{2} \mid \mathrm{H}_{2}$ ase 25 was run with the same loading $(25 \mathrm{pmol})$ and at the same applied potential $(-0.6 \mathrm{~V}$ versus SHE) with $240 \mathrm{mM}$ MES and a bulk pH of 4.24 to demonstrate the increased mass transport of the macroporous structure (Fig. 5). As the local $\mathrm{pH}$ increased less than in the confined mesoITO structure, the local $\mathrm{pH}$ remained below the optimum, and therefore, the current density for $\mathrm{IO}-\mathrm{TiO}_{2}$ was significantly lower $\left(-2.2 \mathrm{~mA} \cdot \mathrm{cm}^{-2}\right)$ than for mesoITO $\left(-4.8 \mathrm{~mA} \cdot \mathrm{cm}^{-2}\right)$. If the local proton consumption is then increased beyond the mass transport limit by doubling the enzyme loading and applying a more reductive potential $\left(\mathrm{IO}-\mathrm{TiO}_{2} \mid \mathrm{H}_{2} \mathrm{ase}_{50}\right)$, the local $\mathrm{pH}$ again
A
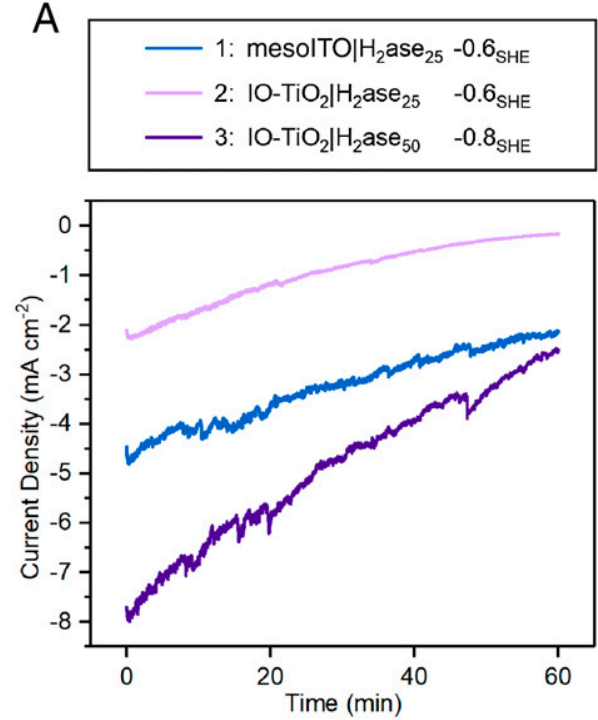
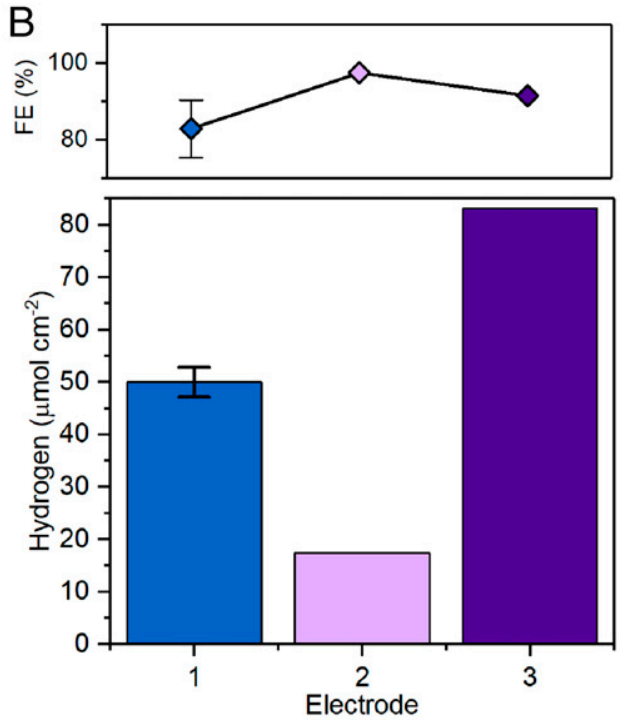

Fig. 5. (A) CA of mesolTO $\mid \mathrm{H}_{2}$ ase $_{25}$ in electrolyte $\mathrm{MES}_{4.24}$ with an applied bias of $-0.6 \mathrm{~V}$ versus $\mathrm{SHE}$ (blue). CA of IO-TiO $2 \mid \mathrm{H}_{2}$ ase 25 in electrolyte $\mathrm{MES}_{4.24}$

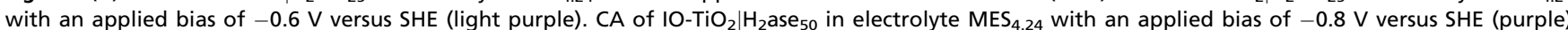
with an applied bias of $-0.8 \mathrm{~V}$ versus SHE. (B) Experimental $\mathrm{H}_{2}$ production and FE from CA after $1 \mathrm{~h}$. Conditions: Electrolyte (MES [240 mM], $\mathrm{KCl}$ [50 mM], $\mathrm{pH}$ 4.24). $\mathrm{DvH}[\mathrm{NiFeSe}] \mathrm{H}_{2} \mathrm{ase}_{25}(25 \mathrm{pmol})$ and $D v \mathrm{H}[\mathrm{NiFeSe}] \mathrm{H}_{2}$ ase $_{50}(50 \mathrm{pmol}), \mathrm{N}_{2}$ atmosphere, stirred, $25^{\circ} \mathrm{C}$. 

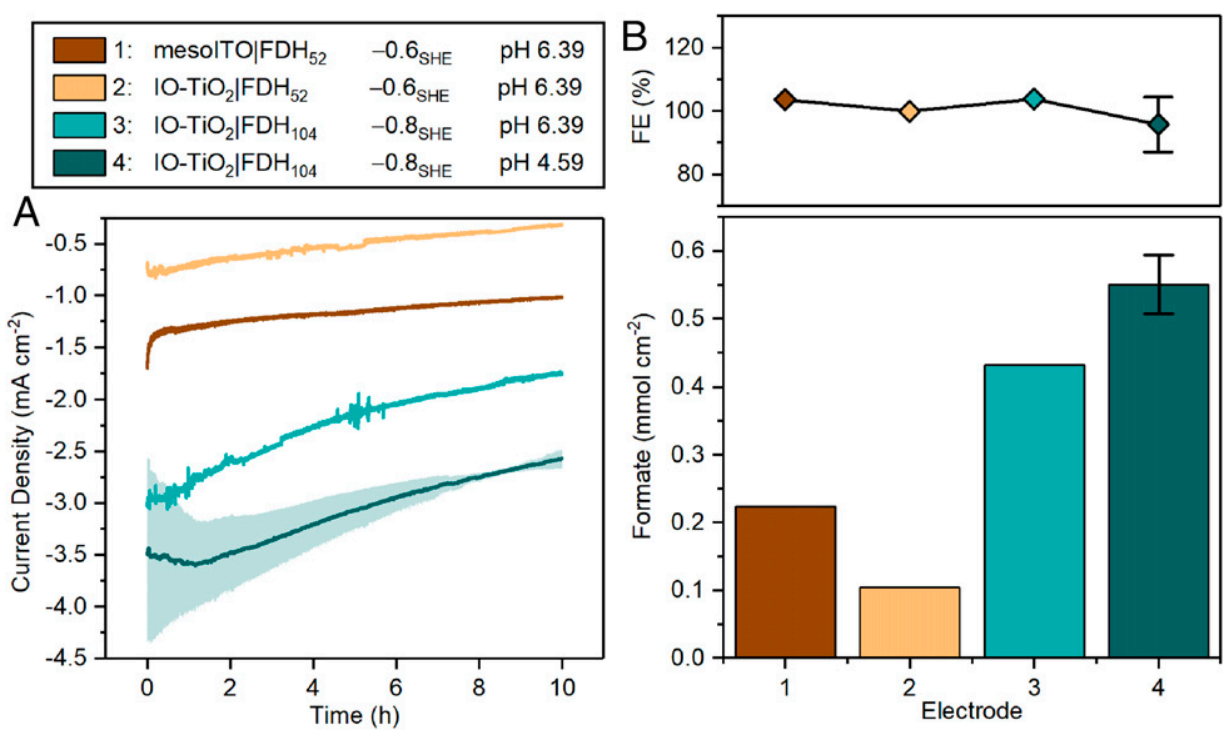

Fig. 6. (A) $\mathrm{CA}$ of mesolTO|FDH $\mathrm{F}_{52}$ with an applied bias of $-0.6 \mathrm{~V}$ versus $\mathrm{SHE}$ in $\mathrm{pH} 6.39$ (brown). $\mathrm{CA}_{\text {of }} \mathrm{IO}_{-\mathrm{TiO}} \mid \mathrm{FDH} \mathrm{F}_{54}$ with an applied bias of $-0.6 \mathrm{~V}$ versus $\mathrm{SHE}$ in $\mathrm{pH} 6.39$ (orange). $\mathrm{CA}$ of $\mathrm{IO}_{-} \mathrm{TiO}_{2} \mid \mathrm{FDH}_{104}$ with an applied bias of $-0.8 \mathrm{~V}$ versus $\mathrm{SHE}$ in $\mathrm{pH} 6.39$ (light green) and in the optimum electrolyte at pH 4.59 (dark green). (B) Experimental formate production and FE from CA after $10 \mathrm{~h}$. Conditions: pH 6.39 (MOPS [86 mM], NaHCO 3 [50 mM], $\mathrm{KCl}$ [50 mM]

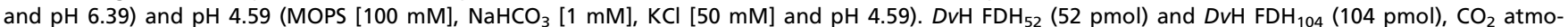
sphere, stirred, $25^{\circ} \mathrm{C}$.

increases as in the mesoporous electrode. Therefore, the current density increased to $-8.0 \mathrm{~mA} \cdot \mathrm{cm}^{-2}$, producing $83 \mu \mathrm{mol} \cdot \mathrm{cm}^{-2}$ of $\mathrm{H}_{2}$ at an $\mathrm{FE}$ of $92 \%$ with an $\mathrm{H}_{2}$ ase-based turnover number (TON) for $\mathrm{H}_{2}$ of $3.2 \cdot 10^{5}$ and TOF of $9 \mathrm{~s}^{-1}$. The TON and TOF were calculated from the product quantification and the enzyme loading, and since the number of active enzymes in direct electron transfer with the surface is unknown, the TON and TOF of these systems therefore represent the lower limits of the actual values. Due to the significantly higher current densities obtained for this system, even greater bubble effects are expected, which can be observed in the decrease in current density over the $1 \mathrm{~h}$ long experiment.

The stability of $\mathrm{CO}_{2}$ reduction by the mesoITO $\mid \mathrm{FDH}_{52}$ electrode with a comparable loading $(52 \mathrm{pmol})$ was demonstrated over $10 \mathrm{~h}$, producing $22 \mu \mathrm{mol} \cdot \mathrm{cm}^{-2} \cdot \mathrm{h}^{-1}$ of formate with a quantitative $\mathrm{FE}$ (Fig. 6). As with $\mathrm{H}_{2}$ ase, the increased mass transport of the macroporous IO structure can be observed by the lower current density of $\mathrm{IO}^{-\mathrm{TiO}_{2}} \mid \mathrm{FDH}_{52}$ at $-0.6 \mathrm{~V}$ versus SHE. On increasing the local proton consumption by again doubling the enzyme loading (104 pmol $\left.\mathrm{IO}-\mathrm{TiO}_{2} \mid \mathrm{FDH}_{104}\right)$ and applying a more reductive potential $(-0.8 \mathrm{~V}$ versus $\mathrm{SHE})$, the local $\mathrm{pH}$ increases, raising the current density to $-3.0 \mathrm{~mA}$. $\mathrm{cm}^{-2}$. However, the local $\mathrm{pH}$ then increases beyond the optimum due to the significantly higher current densities; therefore, the bulk $\mathrm{pH}$ must again be lowered to 4.59 to further increase the enzyme activity. As the increase in local $\mathrm{pH}$ is slower in the less-confined IO structure, the local $\mathrm{pH}$ change can be observed in the chronoamperometry as an initial increase in current density peaking at $1.2 \mathrm{~h}$. The final electrolyte solution demonstrates current densities of $-3.6 \mathrm{~mA} \cdot \mathrm{cm}^{-2}$, producing $0.55 \pm 0.043$ $\mathrm{mmol} \cdot \mathrm{cm}^{-2}$ of formate $\left(55 \pm 4.3 \mu \mathrm{mol} \cdot \mathrm{cm}^{-2} \cdot \mathrm{h}^{-1}\right)$ at an FE of $(96 \pm 8.7) \%$ with an FDH-based TON for formate of $1.0 \cdot 10^{6}$ and TOF of $28 \mathrm{~s}^{-1}$, thus demonstrating the significant 18 -fold improvement that can be achieved compared to previously reported systems $\left(\mathrm{IO}-\mathrm{TiO}_{2} \mid \mathrm{FDH}_{38}, 38 \mathrm{pmol}, 0.2 \mathrm{~mA} \cdot \mathrm{cm}^{-2}\right)$ by simple adjustment of the experimental parameters (39).

\section{Conclusion}

The critical importance of understanding the local chemical environment of highly active confined enzymes in porous electrodes has been experimentally demonstrated. An independent FEM was also applied to predict the experimental currents, thus verifying the model and allowing the simulation and understanding of local concentration changes, an experimentally challenging feat in these complex multicomponent enzyme systems on porous electrodes. For the HER and the $\mathrm{CO}_{2} \mathrm{RR}$, the local $\mathrm{pH}$ was shown to increase around $2 \mathrm{pH}$ units due to enzyme catalysis in a confined environment. Dramatic differences in activity were achieved without inhibitively large buffer concentrations but instead through careful buffer selection and manipulation of the electrolyte $\mathrm{pH}$. In mesoporous electrodes, a ninefold increase in the HER current density from $-0.5 \mathrm{~mA} \cdot \mathrm{cm}^{-2}$ to $-4.8 \mathrm{~mA}$. $\mathrm{cm}^{-2}$ produced $50 \pm 3 \mu \mathrm{mol} \cdot \mathrm{cm}^{-2} \cdot \mathrm{h}^{-1}$ of $\mathrm{H}_{2}$, and a twofold current density increase for $\mathrm{CO}_{2}$ reduction produced $21 \pm 0.1$ $\mu \mathrm{mol} \cdot \mathrm{cm}^{-2} \cdot \mathrm{h}^{-1}$ of formate. Finally, in an alternative architecture of IO electrodes, even greater current densities were achieved through the combination of increased mass transport due to macroporous structuring, higher loading, and more reductive potentials with an optimized electrolyte. For the HER, current densities of $-8.0 \mathrm{~mA} \cdot \mathrm{cm}^{-2}$ produced $80 \mu \mathrm{mol} \cdot \mathrm{cm}^{-2} \cdot \mathrm{h}^{-1}$ $\mathrm{H}_{2}$ with an $\mathrm{FE}$ of $92 \%$, and for the $\mathrm{CO}_{2} \mathrm{RR}$, current densities of $-3.6 \mathrm{~mA} \cdot \mathrm{cm}^{-2}$ produced $55 \pm 4.3 \mu \mathrm{mol} \cdot \mathrm{cm}^{-2} \cdot \mathrm{h}^{-1}$ formate over $10 \mathrm{~h}$, giving a total formate production of $0.55 \pm 0.043 \mathrm{mmol}$ $\cdot \mathrm{cm}^{-2}$ with an FE of $(96 \pm 8.7) \%$. These figures demonstrate a threefold increase for the HER and an 18-fold increase for the $\mathrm{CO}_{2} \mathrm{RR}$ on analogous reported electrochemical systems in which the local environment was not considered $(12,53)$. Through this work, we have shown the ability to use experimental data and computational methods in tandem to analyze and optimize biological-artificial hybrid electrodes.

Electrolyte adjustment to mitigate the local $\mathrm{pH}$ changes of enzymes on a porous electrode has been shown as a simple method to maximize the product formation important for fuelforming applications. While the precise conditions for each system will depend on the enzyme, current density, and electrode architecture, we have demonstrated with the IO electrodes that the following guidelines can be applied to optimize any porous bioelectrochemical system. To achieve this, the bulk $\mathrm{pH}$ should not be chosen for the "ideal" enzyme activity $\mathrm{pH}$ (determined by solution assay) but so that the local $\mathrm{pH}$ changes lead the solution into the optimum range. For proton-consuming reduction reactions, the 
local $\mathrm{pH}$ increases, and therefore a lower $\mathrm{pH}$ should be selected, whereas for proton-releasing oxidation reactions, the local $\mathrm{pH}$ decreases and a higher $\mathrm{pH}$ is appropriate. Then, a buffer should be chosen to have good buffering at the local $\mathrm{pH}$ optimum, which, in a perfect system, will be the "ideal" enzyme activity $\mathrm{pH}$. Further significant developments can be achieved with the utilization of a less densely structured porous electrode to facilitate the mass transport of species. Moreover, as high current density bioelectrochemical systems reach the mass transport limits of current electrode architectures, a shift toward more dynamic flow technology, such as gas diffusion electrodes (54-56), may be required to make advances in the future.

In enzymatic fuel cells, the optimization of the local environment could similarly improve the current performance of these bioelectrochemical devices $(1,57,58)$. Low power output remains one of the key issues that hinder the wider application of enzymatic fuel cells. The densely porous electrodes employed in these systems, such as multiwalled carbon nanotubes, alongside the redox polymers often used to mediate electron transfer will lead to the development of large concentration gradients between the electrodes and the bulk $(1,15,57-59)$. While consideration of the substrate concentration across these electrodes has been made, the local $\mathrm{pH}$ and electrolyte composition has not been accounted for and therefore has the potential to significantly increase power output as shown here for bioelectrochemical fuel synthesis (46).

The negative effect of the local $\mathrm{pH}$ increase in enzymatic $\mathrm{CO}_{2}$ reduction is enhanced compared to systems utilizing synthetic catalysts, as there is no concomitant beneficial change in selectivity against HER. This work demonstrates the increasing importance of studying enzymes as exemplary selective and specific molecular catalysts. As artificial molecular catalysts become more sophisticated, and hence more selective, the techniques and conclusions of this enzymatic research will become ever more applicable.

This study has demonstrated that the local chemical environment is distinctly different when highly active enzymes are confined at high loading under electrocatalytic conditions. This highlights the importance of distinguishing electrochemical techniques into two groups: first, those that easily allow for mechanistic and fundamental enzyme studies, such as the use of unconfined, flat rotating disk electrodes, which minimize mass transport effects and prevent the establishment of local environments (3), and secondly, stationary, porous electrodes, which allow for significantly higher loading and current densities for product application purposes but also establish local chemical environments distinct from the bulk solution. While high-loading porous electrodes can be used in enzymology studies, the local environment changes must be accounted for to prevent misinterpretation of activity changes. A FEM has been shown to be a powerful technique for understanding fundamental experimental observations in highly complex and convoluted applications. This research prompts a variety of other implications not specifically addressed here but of equal importance to the field, including the local concentration of salt species and electron mediators $(60,61)$, the confinement effect of redox polymers (62), the local $\mathrm{pH}$ decrease in oxidation reactions $(15,63)$, and local $\mathrm{pH}$ changes in live cell biofilms (64).

\section{Materials and Methods}

Preparation of mesolTo Electrodes. The mesolTO electrode synthesis was developed from a previously reported procedure (65). A Scotch-tape ring was placed onto the prepared FTO-coated glass to define the geometrical surface area as $0.19 \mathrm{~cm}^{2}$. The $50 \mathrm{~nm}$ ITO nanoparticles (43 $\mathrm{mg}$ ) were dispersed in an acetic acid $(57 \mu \mathrm{L})$ and ethanol $(143 \mu \mathrm{L})$ mixture by sonication for $>1 \mathrm{~h}$ at 45 to

1. H. Chen et al., Fundamentals, applications, and future directions of bioelectrocatalysis. Chem. Rev. 120, 12903-12993 (2020).

2. N. Kornienko, J. Z. Zhang, K. K. Sakimoto, P. Yang, E. Reisner, Interfacing nature's catalytic machinery with synthetic materials for semi-artificial photosynthesis. Nat. Nanotechnol. 13, 890-899 (2018). $55^{\circ} \mathrm{C}$ in a sealed vial. A total of $5 \mu \mathrm{L}$ cooled ITO suspension was dropcast onto the predefined area and, after $10 \mathrm{~s}$, spin-coated at $1,000 \mathrm{rpm}$ for $30 \mathrm{~s}$. Finally, the electrodes were heated at a rate of $4{ }^{\circ} \mathrm{C} \cdot \mathrm{min}^{-1}$ from room temperature to $400^{\circ} \mathrm{C}$ and annealed at this temperature for $1 \mathrm{~h}$. The resulting electrodes had a geometrical surface area of $0.19 \mathrm{~cm}^{2}$ and an average film thickness of $8.5 \mu \mathrm{m}$ (SI Appendix, Fig. S4).

Preparation of $10-\mathrm{TiO}_{2}$ Electrodes. The $1 \mathrm{O}-\mathrm{TiO}_{2}$ electrode synthesis was employed from a previously reported coassembly procedure $(12,62)$. A mixed dispersion of $\mathrm{TiO}_{2}$ anatase nanoparticles ( $21 \mathrm{~nm}$ diameter) and polystyrene beads ( $750 \mathrm{~nm}$ diameter, $2.54 \% \mathrm{wt} / \mathrm{vol}$ suspension in water) was prepared as follows: $\mathrm{TiO}_{2}$ anatase nanoparticles $(30 \mathrm{mg}$ ) were dispersed by sonication in a water/MeOH mixture (4:1 volume/volume) (346 $\mu \mathrm{L})$ for $2 \mathrm{~h}$. The dispersion of polystyrene spheres $(1,000 \mu \mathrm{L})$ was centrifuged, the supernatant removed, and the polystyrene pellet redispersed in $\mathrm{MeOH}(1,000 \mu \mathrm{L})$. The polystyrene dispersion was centrifuged again, the supernatant removed, and the dispersion of $\mathrm{TiO}_{2}$ nanoparticles added to the polystyrene pellet. The mixture was then vortexed and sonicated for $5 \mathrm{~min}$ in ice-cold water $\left(<5^{\circ} \mathrm{C}\right)$ to give the polystyrene- $\mathrm{TiO}_{2}$ dispersion, which was used immediately.

A parafilm ring was placed onto the prepared FTO-coated glass to define the geometrical surface area for the $1 \mathrm{O}-\mathrm{TiO}_{2}$ films as $0.19 \mathrm{~cm}^{2}$. An amount of 4 $\mu \mathrm{L}$ of the described polystyrene- $\mathrm{TiO}_{2}$ dispersion drop cast onto the substrate corresponded to a $40 \mu \mathrm{m}$ thick $10-\mathrm{TiO}_{2}$ structure. The electrodes were heated at a rate of $1^{\circ} \mathrm{C} \cdot \mathrm{min}^{-1}$ from room temperature to $500^{\circ} \mathrm{C}$ and annealed at this temperature for $20 \mathrm{~min}$. The resulting electrodes had a geometrical surface area of $0.19 \mathrm{~cm}^{2}$ and a film thickness of $40 \mu \mathrm{m}$ (SI Appendix, Fig. S6).

Preparation of $\mathbf{H}_{2}$ ase Electrodes. [NiFeSe] $\mathrm{H}_{2}$ ase $(2.5 \mu \mathrm{L}, 25$ pmol or $5 \mu \mathrm{L}, 50$ pmol) was drop cast onto the mesolTO or $\mathrm{IO}^{-\mathrm{TiO}_{2}}$ electrode and incubated under inert conditions for $3 \mathrm{~min}$ or $6 \mathrm{~min}$, respectively.

Preparation of FDH Electrodes. An $80 \mathrm{mM}$ solution of dithiothreitol (DTT) was made up in Tris. $\mathrm{HCl}(20 \mathrm{mM}, \mathrm{pH} 7.7)$. FDH (1.3 $\mu \mathrm{L}, 52 \mathrm{pmol}$ or $2.6 \mu \mathrm{L}, 104 \mathrm{pmol})$ was incubated with the DTT solution $(2.5 \mu \mathrm{L})$ under inert conditions for $5 \mathrm{~min}$ The FDH-DTT solution was then drop cast onto the mesolTO or IO-TiO 2 electrode and incubated under inert conditions for $6 \mathrm{~min}$ or $12 \mathrm{~min}$, respectively.

Electrochemical Measurements. Cyclic voltammetry and chronoamperometry were performed in a three-electrode configuration with the working electrode located in the same compartment as the $\mathrm{Ag} / \mathrm{AgCl}(\mathrm{KCl}$ saturated) reference electrode and the Pt counter electrode in the other compartment. A Nafion ion-exchange membrane was used to separate the compartments. All potentials have been quoted versus $\mathrm{SHE}$ using the conversion $\mathrm{E}_{\mathrm{SHE}}=\mathrm{E}_{\mathrm{Ag} / \mathrm{AgCl}}+$ $0.197 \mathrm{~V}\left(25^{\circ} \mathrm{C}\right)$. Cyclic voltammetry experiments were performed with a scan rate of $5 \mathrm{mV} \cdot \mathrm{s}^{-1}$. The electrochemical cell was filled with the listed electrolyte solution, and each solution was stirred at the same rate. For $\mathrm{CO}_{2} \mathrm{RR}$ experiments, the cell was sealed and filled with the $\mathrm{CO}_{2}$ purged electrolyte, and each cell compartment was then purged a second time for $>5$ min each.

Supporting Information. The Supporting information contains the following: theory and simulation derivations, experimental procedures, SEM of the mesolTO and $1 \mathrm{O}-\mathrm{TiO}_{2}$ electrodes, three-dimensional representation of the $\mathrm{H}_{2}$ ase and $\mathrm{FDH}$ enzyme, supporting electrochemical experiments, simulation of the $\mathrm{pH}$ and buffer capacity as a function of the distance from the surface, the Good's buffer concentration-activity solution, and electrochemical assays.

A full output report from the COMSOL model has also been included as additional information in Dataset. The parameters listed in this report relate to the BC-MOPS model, but the model construction and boundary conditions relate to all simulations.

Data Availability. All study data are included in the article, SI Appendix, and/or the Cambridge Open Data Repository (https://doi.org/10.17863/CAM.77893).

ACKNOWLEDGMENTS. This work was supported by a European Research Council Consolidator Grant (No. 682833; E.E.M., S.J.C., and E.R.), the Leverhulme Trust (P80336; S.J.C. and E.R.), Fundação para a Ciência e Tecnologia Grant PTDC/BII-BBF/2050/2020 (I.A.C.P.), fellowships SFRH/BD/116515/2016 (A.R.O.) and SFRH/BD/146475/2019 (A.M.C.), and the Molecular, Structural and Cellular Microbiology unit of Instituto de Tecnologia Química e Biológica (UIDB/04612/ 2020 and UIDP/04612/2020).

3. M. Del Barrio et al., Electrochemical investigations of hydrogenases and other enzymes that produce and use solar fuels. Acc. Chem. Res. 51, 769-777 (2018).

4. W. Lubitz, H. Ogata, O. Rüdiger, E. Reijerse, Hydrogenases. Chem. Rev. 114, 4081-4148 (2014) 
5. A. Parkin, J. Seravalli, K. A. Vincent, S. W. Ragsdale, F. A. Armstrong, Rapid and efficien electrocatalytic $\mathrm{CO}_{2} / \mathrm{CO}$ interconversions by Carboxydothermus hydrogenoformans CO dehydrogenase I on an electrode. J. Am. Chem. Soc. 129, 10328-10329 (2007).

6. W. E. Robinson, A. Bassegoda, E. Reisner, J. Hirst, Oxidation-state-dependent binding properties of the active site in a Mo-containing formate dehydrogenase. J. Am. Chem. Soc. 139, 9927-9936 (2017).

7. T. Reda, C. M. Plugge, N. J. Abram, J. Hirst, Reversible interconversion of carbon dioxide and formate by an electroactive enzyme. Proc. Natl. Acad. Sci. U.S.A. 105, 10654-10658 (2008)

8. A. Bassegoda, C. Madden, D. W. Wakerley, E. Reisner, J. Hirst, Reversible interconversion of $\mathrm{CO}_{2}$ and formate by a molybdenum-containing formate dehydrogenase. $\mathrm{J}$. Am. Chem. Soc. 136, 15473-15476 (2014).

9. K. A. Vincent, A. Parkin, F. A. Armstrong, Investigating and exploiting the electrocatalytic properties of hydrogenases. Chem. Rev. 107, 4366-4413 (2007).

10. X. Fang et al., Structure-activity relationships of hierarchical three-dimensional electrodes with photosystem II for semiartificial photosynthesis. Nano Lett. 19, 1844-1850 (2019)

11. K. P. Sokol et al., Rational wiring of photosystem II to hierarchical indium tin oxide electrodes using redox polymers. Energy Environ. Sci. 9, 3698-3709 (2016).

12. E. Edwardes Moore, V. Andrei, S. Zacarias, I. A. C. Pereira, E. Reisner, Integration of a hydrogenase in a lead halide perovskite photoelectrode for tandem solar water splitting. ACS Energy Lett. 5, 232-237 (2020).

13. S. K. Kuk et al., Continuous 3D titanium nitride nanoshell structure for solar-driven unbiased biocatalytic $\mathrm{CO}_{2}$ reduction. Adv. Energy Mater. 9, 1900029 (2019).

14. X. Luo, M. Brugna, P. Tron-Infossi, M. T. Giudici-Orticoni, E. Lojou, Immobilization of the hyperthermophilic hydrogenase from Aquifex aeolicus bacterium onto gold and carbon nanotube electrodes for efficient $\mathrm{H}_{2}$ oxidation. J. Biol. Inorg. Chem. 14 1275-1288 (2009).

15. E. Lojou, Hydrogenases as catalysts for fuel cells: Strategies for efficient immobilization at electrode interfaces. Electrochim. Acta 56, 10385-10397 (2011).

16. A. R. Oliveira et al., Toward the mechanistic understanding of enzymatic $\mathrm{CO}_{2}$ reduc tion. ACS Catal. 10, 3844-3856 (2020).

17. X. Yu, D. Niks, A. Mulchandani, R. Hille, Efficient reduction of $\mathrm{CO}_{2}$ by the molybdenum-containing formate dehydrogenase from Cupriavidus necator (Ralstonia eutropha). J. Biol. Chem. 292, 16872-16879 (2017).

18. S. Zacarias et al., Characterization of the [NiFeSe] hydrogenase from Desulfovibrio vulgaris Hildenborough. Methods Enzymol. 613, 169-201 (2018).

19. E. B. Carneiro-Neto, M. C. Lopes, E. C. Pereira, Simulation of interfacial pH changes during hydrogen evolution reaction. J. Electroanal. Chem. 765, 92-99 (2016).

20. A. M. Appel et al., Frontiers, opportunities, and challenges in biochemical and chemical catalysis of $\mathrm{CO}_{2}$ fixation. Chem. Rev. 113, 6621-6658 (2013).

21. T. Burdyny et al., Nanomorphology-enhanced gas-evolution intensifies $\mathrm{CO}_{2}$ reduc tion electrochemistry. ACS Sustain. Chem. Eng. 5, 4031-4040 (2017).

22. M. R. Singh, E. L. Clark, A. T. Bell, Effects of electrolyte, catalyst, and membrane composition and operating conditions on the performance of solar-driven electrochemical reduction of carbon dioxide. Phys. Chem. Chem. Phys. 17, 18924-18936 (2015).

23. C. Delacourt, J. Newman, Mathematical modeling of $\mathrm{CO}_{2}$ reduction to $\mathrm{CO}$ in aqueous electrolytes: II. Study of an electrolysis cell making syngas $\left(\mathrm{CO}+\mathrm{H}_{2}\right)$ from $\mathrm{CO}_{2}$ and $\mathrm{H}_{2} \mathrm{O}$ reduction at room temperature. J. Electrochem. Soc. 157, B1926 (2010).

24. J. Li, Y. Zhang, N. Kornienko, Heterogeneous electrocatalytic reduction of $\mathrm{CO}_{2}$ promoted by secondary coordination sphere effects. New J. Chem. 44, 4246-4252 (2020).

25. A. S. Varela et al., PH effects on the selectivity of the electrocatalytic $\mathrm{CO}_{2}$ reduction on graphene-embedded Fe- $\mathrm{N}-\mathrm{C}$ motifs: Bridging concepts between molecular homogeneous and solid-state heterogeneous catalysis. ACS Energy Lett. 3, 812-817 (2018).

26. A. S. Varela, M. Kroschel, T. Reier, P. Strasser, Controlling the selectivity of $\mathrm{CO}_{2}$ elec troreduction on copper: The effect of the electrolyte concentration and the importance of the local pH. Catal. Today 260, 8-13 (2016).

27. N. Morlanés, K. Takanabe, V. Rodionov, Simultaneous reduction of $\mathrm{CO}_{2}$ and splitting of $\mathrm{H}_{2} \mathrm{O}$ by a single immobilized cobalt phthalocyanine electrocatalyst. ACS Catal. 6, 3092-3095 (2016)

28. J. S. Zeng, N. Corbin, K. Williams, K. Manthiram, Kinetic analysis on the role of bicarbonate in carbon dioxide electroreduction at immobilized cobalt phthalocyanine. ACS Catal. 10, 4326-4336 (2020).

29. M. Zhu, R. Ye, K. Jin, N. Lazouski, K. Manthiram, Elucidating the reactivity and mechanism of $\mathrm{CO}_{2}$ electroreduction at highly dispersed cobalt phthalocyanine. ACS Energy Lett. 3, 1381-1386 (2018).

30. R. Kas, R. Kortlever, H. Yılmaz, M. T. M. Koper, G. Mul, Manipulating the hydrocarbon selectivity of copper nanoparticles in $\mathrm{CO}_{2}$ electroreduction by process conditions. ChemElectroChem 2, 354-358 (2015).

31. A. S. Hall, Y. Yoon, A. Wuttig, Y. Surendranath, Mesostructure-induced selectivity in $\mathrm{CO}_{2}$ reduction catalysis. J. Am. Chem. Soc. 137, 14834-14837 (2015).

32. V. Svetlitchnyi, C. Peschel, G. Acker, O. Meyer, Two membrane-associated NiFeS-carbon monoxide dehydrogenases from the anaerobic carbon-monoxide-utilizing eubacterium Carboxydothermus hydrogenoformans. J. Bacteriol. 183, 5134-5144 (2001)

33. V. C. C. Wang, S. T. A. Islam, M. Can, S. W. Ragsdale, F. A. Armstrong, Investigations by protein film electrochemistry of alternative reactions of nickel-containing carbon monoxide dehydrogenase. J. Phys. Chem. B 119, 13690-13697 (2015).

34. M. C. Marques et al., The direct role of selenocysteine in [NiFeSe] hydrogenase maturation and catalysis. Nat. Chem. Biol. 13, 544-550 (2017).
35. C. Renault et al., Unraveling the mechanism of catalytic reduction of $\mathrm{O}_{2}$ by microperoxidase-11 adsorbed within a transparent 3D-nanoporous ITO film. J. Am. Chem. Soc. 134, 6834-6845 (2012).

36. Y. Liu et al., Macroporous indium tin oxide electrode layers as conducting substrates for immobilization of bulky electroactive guests. Electrochim. Acta 140, 108-115 (2014).

37. D. Schaming et al., Spectroelectrochemical characterization of small hemoproteins adsorbed within nanostructured mesoporous ITO electrodes. Langmuir 28, 14065-14072 (2012).

38. B. Reuillard et al., High performance reduction of $\mathrm{H}_{2} \mathrm{O}_{2}$ with an electron transport decaheme cytochrome on a porous ITO electrode. J. Am. Chem. Soc. 139, 3324-3327 (2017).

39. K. P. Sokol et al., Reversible and selective interconversion of hydrogen and carbon dioxide into formate by a semiartificial formate hydrogenlyase mimic. J. Am. Chem. Soc. 141, 17498-17502 (2019).

40. M. Kato, T. Cardona, A. W. Rutherford, E. Reisner, Photoelectrochemical water oxidation with photosystem II integrated in a mesoporous indium-tin oxide electrode. J. Am. Chem. Soc. 134, 8332-8335 (2012).

41. D. Ciornii et al., Bioelectronic circuit on a 3D electrode architecture: Enzymatic catalysis interconnected with photosystem I. J. Am. Chem. Soc. 139, 16478-16481 (2017).

42. R. N. Goldberg, N. Kishore, R. M. Lennen, Thermodynamic quantities for the ionization reactions of buffers. J. Phys. Chem. Ref. Data 31, 231-370 (2002).

43. W. J. Ferguson et al., Hydrogen ion buffers for biological research. Anal. Biochem. 104, 300-310 (1980).

44. C. M. H. Ferreira, I. S. S. Pinto, E. V. Soares, H. M. V. M. Soares, (Un)suitability of the use of $\mathrm{pH}$ buffers in biological, biochemical and environmental studies and their interaction with metal ions-a review. RSC Adv. 5, 30989-31003 (2015).

45. J. P. Gustafsson, Visual MINTEQ ver. 3.1 (2014), 14 April 2020.

46. I. Mazurenko et al., Impact of substrate diffusion and enzyme distribution in 3D-porous electrodes: A combined electrochemical and modelling study of a thermostable $\mathrm{H}_{2} / \mathrm{O}_{2}$ enzymatic fuel cell. Energy Environ. Sci. 10, 1966-1982 (2017).

47. V. Fourmond et al., Mechanism of protection of catalysts supported in redox hydrogel films. J. Am. Chem. Soc. 137, 5494-5505 (2015).

48. D. H. Nam et al., Solar water splitting with a hydrogenase integrated in photoelectrochemical tandem cells. Angew. Chem. Int. Ed. Engl. 57, 10595-10599 (2018).

49. A. Parkin, G. Goldet, C. Cavazza, J. C. Fontecilla-Camps, F. A. Armstrong, The difference a Se makes? Oxygen-tolerant hydrogen production by the [NiFeSe]-hydrogenase from Desulfomicrobium baculatum. J. Am. Chem. Soc. 130, 13410-13416 (2008)

50. A. Wuttig, Y. Yoon, J. Ryu, Y. Surendranath, Bicarbonate is not a general acid in Au-catalyzed $\mathrm{CO}_{2}$ electroreduction. J. Am. Chem. Soc. 139, 17109-17113 (2017).

51. J. Al-Gousous et al., Mass transport analysis of bicarbonate buffer: Effect of the $\mathrm{CO}_{2}$ $\mathrm{H}_{2} \mathrm{CO}_{3}$ hydration-dehydration kinetics in the fluid boundary layer and the apparent effective $\mathrm{p} \mathrm{K}_{\mathrm{a}}$ controlling dissolution of acids and bases. Mol. Pharm. 16, 2626-2635 (2019).

52. B. J. Krieg, S. M. Taghavi, G. L. Amidon, G. E. Amidon, In vivo predictive dissolution: Transport analysis of the $\mathrm{CO}_{2}$, bicarbonate in vivo buffer system. J. Pharm. Sci. 103, 3473-3490 (2014).

53. K. P. Sokol et al., Photoreduction of $\mathrm{CO}_{2}$ with a formate dehydrogenase driven by photosystem II using a semi-artificial Z-scheme architecture. J. Am. Chem. Soc. 140, 16418-16422 (2018).

54. T. Krieg, S. Hüttmann, K. M. Mangold, J. Schrader, D. Holtmann, Gas diffusion elec trode as novel reaction system for an electro-enzymatic process with chloroperoxidase. Green Chem. 13, 2686-2689 (2011).

55. T. Krieg, A. Sydow, U. Schröder, J. Schrader, D. Holtmann, Reactor concepts for bioelec trochemical syntheses and energy conversion. Trends Biotechnol. 32, 645-655 (2014).

56. J. Szczesny et al., Electroenzymatic $\mathrm{CO}_{2}$ fixation using redox polymer/enzyme-modified gas diffusion electrodes. ACS Energy Lett. 5, 321-327 (2020).

57. X. Xiao et al., Tackling the challenges of enzymatic (bio)fuel cells. Chem. Rev. 119, 9509-9558 (2019).

58. M. T. Meredith, S. D. Minteer, Biofuel cells: Enhanced enzymatic bioelectrocatalysis. Annu. Rev. Anal. Chem. 5, 157-179 (2012).

59. K. Elouarzaki, D. Cheng, A. C. Fisher, J. M. Lee, Coupling orientation and mediation strategies for efficient electron transfer in hybrid biofuel cells. Nat. Energy 3, 574-581 (2018).

60. C. F. Megarity et al., Electrocatalytic volleyball: Rapid nanoconfined nicotinamide cycling for organic synthesis in electrode pores. Angew. Chem. Int. Ed. Engl. 58, 4948-4952 (2019).

61. E. Edwardes Moore et al., A semi-artificial photoelectrochemical tandem leaf with a $\mathrm{CO}_{2}$-to-formate efficiency approaching 1\%. Angew. Chem. Int. Ed. Engl. 60, 26303-26307 (2021).

62. H. Li et al., Complete protection of $\mathrm{O}_{2}$-sensitive catalysts in thin films. J. Am. Chem. Soc. 141, 16734-16742 (2019).

63. D. Mersch et al., Wiring of photosystem II to hydrogenase for photoelectrochemical water splitting. J. Am. Chem. Soc. 137, 8541-8549 (2015).

64. X. Fang, S. Kalathil, G. Divitini, Q. Wang, E. Reisner, A three-dimensional hybrid electrode with electroactive microbes for efficient electrogenesis and chemical synthesis. Proc. Natl. Acad. Sci. U.S.A. 117, 5074-5080 (2020).

65. T. E. Rosser, M. A. Gross, Y. H. Lai, E. Reisner, Precious-metal free photoelectrochemical water splitting with immobilised molecular Ni and Fe redox catalysts. Chem. Sci. 7, 4024-4035 (2016). 